is usually happy, in several cases it emphasizes the advantage of giving a number of methods as Whipple, for example, has done. Selection may be necessary for the tyro, but even he should be given a choice after some one method has been recommended for first trial. W. B. P.

\title{
COLORBLINDNESS
}

Ein Fall von Gelbblau-Blindheit. S. Alrutz. Atti del V congresso internazionale di psicologia. Roma: Forzani, 1906. Pp. 217218.

In view of the fact that there is a widespread interest in the facts of color vision and in color theories, it is peculiar that no notice has heretofore been taken in any of our psychological journals of the case of colorblindness which Professor Alrutz, of the University of Upsala, reported at the Rome Congress of Psychology. The importance of this general type of case is surely a sufficient excuse for a review at so late a date.

The subject, born in 1885 , was a student at the University of Upsala. He was not aware of any change in his color sense, nor of any colorblindness in his family. He has had no difficulty in discriminating the red of berries from the green of leaves, but has had difficulty in distinguishing at a distance the blue hepatica from the green leaves, and in recognizing the yellow cross on the blue field in the Swedish flag.

In a test with the Holmgren wools, he confused the yellow-green, green-blue, and pure blue wools, with the green test skein; with the purple skein red and brown were confused, though he noted a difference in texture-the purple appeared uneven (fleckig); and with the red skein the purples were confused, though with the same reservations as to the homogeneity in the coloring of the reds.

An examination made with an arclight spectrum showed it to be perceived as unshortened. There was one color from the beginning of the spectrum in red, to a neutral zone, which began in yellow-green; this neutral zone he saw as grey 'sehr unbestimmt und ungesättigt'; beyond that, one color extended to the edge of the violet, where a second neutral zone was perceived; then red to the end of the spectrum.

An accurate determination with the Hoffman spectroscope ' $a$ vision directe' and with the sunlight gave the following results: The first color, which was called red, was most saturated at $655-650 \mathrm{~mm}$. and most intense (lichtstarke) at $637 \mathrm{~mm}$.; the saturation and intensity 
decreased more and more toward yellow; the neutral zone lay between 570 and $562 \mathrm{~mm}$., and had about the same intensity as the contiguous red on the left, and green on the right. The second color was called green, and was most intense at $507 \mathrm{~mm}$., most saturated at $480 \mathrm{~mm}$., and darkest in blue. A second neutral zone was found at the boundary between the blue and violet $(467-464 \mathrm{~mm}$.); it was still darker than the first. The third color, that of a newly advancing red, was darker, and not so homogeneous as the first red band, "aber doch etwas andersartig, als wenn etwas ausgefallen wäre, wie auf einem schwarzen Grunde."

A later determination with a Steinheils spectroscope, and a Nernst lamp, gave the following limits: Red, $790-770 \mathrm{~mm}$. to $579-$; neutral (white) 579-576; green 576-460; neutral (red and green) 460-450; 'red and black' 450 to beyond $400 \mathrm{~mm}$.

The visual field is evidently not at all diminished. Red, yellow, and purple pass directly from white to red, and the green is constant. A dark blue passes from white, through red, into green.

An ophthalmological test showed that the colorblindness could not have resulted through any variation in the media of the eye.

Professor Alrutz is of the opinion that this case does not correspond to any case hitherto known.

Florence Richardson

Drake University

\section{REPORT OF THE COMMITTEE ON TESTS}

Report of the Committee of the American Psychological Association on the Standardizing of Procedure in Experimental Tests. Psxchological Monographs. Vol. XIII., No. 1, I9Io. Whole No. 53. Pp. 107.

In 1906 the American Psychological Association authorized the "creation of a permanent committee of the Association, to consist of five members, which shall act as a general control committee on the subject of measurements." It was recommended that this committee "undertake two general lines of work, organizing as many subcommittees as it shall see fit, and calling to its assistance such outside help as it may desire: first, the determination of a series of group and individual tests, with reference to practical application, and second, the determination of standard experiments of a more technical character." The present publication contains the reports of three members of the committee. 